\title{
Performance of Upland Rice Crop Depending on Plant Spacing and Nitrogen Levels
}

\author{
Moisés S. Reis ${ }^{1}$, Natalia B. Alves ${ }^{2}$, Douglas G. Castro², Flávia B. S. Botelho ${ }^{2}$, \\ Laís M. Tomé ${ }^{2}$ \& Aurinelza B. T. Cornélio ${ }^{1}$ \\ ${ }^{1}$ Minas Gerais Company of Agricultural Research (EPAMIG), Lavras, Minas Gerais State, Brazil \\ ${ }^{2}$ Agricultural Departament, Federal University of Lavras, Lavras, Minas Gerais State, Brazil \\ Correspondence: Douglas G. Castro, Agricultural Department, Federal University of Lavras, Lavras, Minas \\ Gerais, Brazil. Tel: 55-359-9153-8018. E-mail: douglasgoulartcastro@gmail.com
}

Received: February 10, 2019 Accepted: March 20, $2019 \quad$ Online Published: May 15, 2019

doi:10.5539/jas.v11n6p344 URL: https://doi.org/10.5539/jas.v11n6p344

\begin{abstract}
The aim of the present study was to determine the dose of Nitrogen and plant spacing of BRSMG Caravera, a modern rice cultivar, in order to maximize grain yield and increase rice production in the state of Minas Gerais, Brazil. The following characteristics were evaluated: grain yield (GY), percentage of filled grains (\% F), 100 grains weight $(100 \mathrm{GW})$ and plant height $(\mathrm{H})$. It was used a $4 \times 4$ factorial design, with four row spacings $(20,30$, 40 and $50 \mathrm{~cm})$ and four nitrogen rates $\left(0,40,80\right.$ and $\left.120 \mathrm{~kg} \mathrm{ha}^{-1}\right)$ totaling 16 treatments. The phenotypes were analyzed through the Scott-Knott mean test together with an analysis for significant interactions to identify the spacing and the $\mathrm{N}$ rates associated with the best trait averages. Differences in plant spacing were associated with significant differences in $\mathrm{GY}, \% \mathrm{~F}$ and $\mathrm{H}$, whereas different $\mathrm{N}$ rates were associated with significant differences of $\mathrm{GY}$ and $\mathrm{H}$. When considering the interaction between plant spacing and $\mathrm{N}$ rates, significant differences could be identified for all traits, indicating that these factors should be considered together. The highest grain yield was achieved with spacing of $20 \mathrm{~cm}$ and $\mathrm{N}$ rate of $120 \mathrm{~kg} \mathrm{ha}^{-1}$. The use of modern cultivars, the adequate spacing and $\mathrm{N}$ dose can significantly increase grain yield and competitiveness of upland rice cultivation, in the state of Minas Gerais, Brazil.
\end{abstract}

Keywords: Oryza sativa, nitrogen fertilization, rice cultivation

\section{Introduction}

During the 80 's, upland rice accounted for up to $61 \%$ the planted area in Brazil and for $50 \%$ this type of production in Minas Gerais, Brazil (Minas Gerais, 1995). However, the low productivity of upland rice associated with water deficiency, low prices and competition with irrigated lowland rice in the south of the country (with better cooking quality) contributed to a drastic reduction in the planted area in Minas Gerais. Thus, Minas Gerais that once was self-sufficient in this cereal, today produces less than $10 \%$ of what is consumed in the state and became a major importer of rice from other States, Rio Grande do Sul mainly.

Upland rice production has been conducted in areas with sprinkler irrigation, using center pivot or conventional irrigation system. The main obstacle to growing rice under center pivot is the lack of cultivars adapted to sprinkler irrigation, because the most common cultivars are of high size, vulnerable to lodging, long class grains, have regular cooking quality and low response to high technology, notably to nitrogen fertilization.

In order to solve this problem, modern cultivars suitable to this cultivation system such as Canastra, Charisma, BRSMG Curinga and BRSMG Caravera cultivars were developed and recommended to production in the state of Minas Gerais. These cultivars have low/intermediate-sized, resistance to lodging, tillers, have upright leaves, white type grains and have expressively good response to nitrogen fertilization. According to Sant'Ana (1989), the spacing for these cultivars can be reduced to that used for traditional dryland crops.

Despite the availability of modern cultivars, there is still little information on the effect of nitrogen fertilization and the use of different spacings in rice grain yield and other traits of interest to the producer. It is believed that the use of modern cultivars with greater yield stability in association with the useof appropriate spacing and heavy fertilizer, especially nitrogen, could boost rice production in Minas Gerais, causing the state once again 
become self-sufficient in the production of this cereal. The aim of this study was to determine the $\mathrm{N}$ rate and plant spacing to maximize grain yield in upland rice cultivation irrigated by sprinkling.

\section{Materials and Methods}

\subsection{Study Area Description}

The experiments were carried out at the Experimental Farm of the Agricultural Research Company of Minas

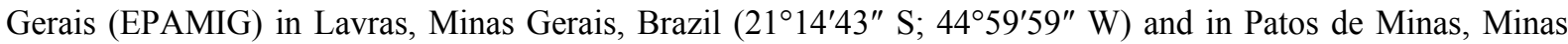
Gerais, Brazil (18 $34^{\prime} 44^{\prime \prime}$ S; 46 $31^{\prime} 05^{\prime \prime}$ W), in 2012/2013 and 2013/2014 agricultural years, corresponding to four environments.

\subsection{Plant Materials}

The modern rice cultivar BRSMG Caravera, developed and recommended to production in the state of Minas Gerais was used in this study. The cultivar presents medium height $(95 \mathrm{~cm})$, resistance to lodging, semi-early cycle, moderate susceptibility to blast and adaptation in the sprinkler irrigation system.

\subsection{Experimental Design}

The plots contained $5 \mathrm{~m}$ long by $2.4 \mathrm{~m}$ wide, density of 80 seeds. $\mathrm{m}^{-1}$ and a variable number of lines according to spacing tested (5, 6, 8 or 12 lines). Surroundings consisted of two lateral lines of $0.5 \mathrm{~m}$ from the ends of the central lines, resulting in useful areas of $8 \mathrm{~m}^{2}, 7.2 \mathrm{~m}^{2}, 6.4 \mathrm{~m}^{2}$ and $5.76 \mathrm{~m}^{2}$ per plot for the spacings of 20,30,40 and $50 \mathrm{~cm}$, respectively.

Cultural practices and weed control were performed according to climate conditions, the cultivation treatments used in the experiments were the same as those recommended for upland rice cultivation in the state.

\subsection{Characteristics Evaluated}

The following phenotypic characteristics were evaluated, according to the Rice Research Methods Manual (EMBRAPA, 1977): (1) grain yield $\left(\mathrm{kg} \mathrm{ha}^{-1}\right)$, in grams per plot adjusted for kg.ha ${ }^{-1}$, referring to the plot useful area, calculated after correction for $13 \%$ moisture; (2) percentage of filled grain, provided by the proportion of full grains to the total number of grains; (3) 100 grains weight, corresponding to an average of three samples in grams; and (4) plant height, corresponding to the average of five plants per plot measured from the ground level to the end of the panicle of the main stem.

It was analyzed four traits, according to the Rice Research Methods Manual (EMBRAPA, 1977): (1) grain yield

\subsection{Statistical Analyzis}

Combined analyzis of variance was performed following the experimental design of randomized blocks and considering two models: in the first model row spacing and nitrogen rate were considered as separate sources of variation, differently, in the second model was also included the interaction between row spacing and nitrogen rate. Statistical interactions and Scott-Knott test (1974) were performed to verify which spacings and N rates provided better averages. Analyzis were performed using the statistical R software (R Development Core Team, 2012).

\section{Results}

Significant differences were observed $(\mathrm{P}<0.05)$ among the treatments and the interaction treatment $x$ environments in the joint variance analyzis for all traits. When considering plant spacing and nitrogen rate separately, the spacing variable was significantly associated with yield and plant height whereas the nitrogen rate variable was significantly associated with all the traits apart from 100 grains weight. When considering the interaction between plant spacing and nitrogen rate, significant differences could be detected only for the $\%$ of filled grains. Conversely, plant spacing $\times$ environment interaction was associated with yield, 100 grains weight and plant height, indicating that different spacings provided differential performances in the averages for these traits in different environments. The interaction between $\mathrm{N}$ rate and environment was significantly associated only with yield and 100 grains weight, indicating that responses of these traits were differential in environments according to the $\mathrm{N}$ rate. The summary of the analyzes of variance with the main sources of variation for each trait is presented in Table 1 . 
Table 1. Summary for analyzis of variance for: grain yield, percent of filled grains, 100 grains weight and plant height, measured using four spacings and four rates of $\mathrm{N}$ in four environments

\begin{tabular}{|c|c|c|c|c|c|}
\hline SV & DF & MS GY & $\mathrm{MS} \% \mathrm{~F}$ & MS W100G & MS H \\
\hline \multicolumn{6}{|l|}{ Model 1} \\
\hline Spacing & 3 & $6695074 * * *$ & $60.864 \mathrm{~ns}$ & $0.0313 \mathrm{~ns}$ & $105.8 * * *$ \\
\hline $\mathrm{N}$ rate & 3 & $5963456^{* * *}$ & $73.351^{*}$ & $0.0641 \mathrm{~ns}$ & $280.7 * * *$ \\
\hline SxR Int. & 9 & $270234 n s$ & $72.156^{* *}$ & $0.0441 \mathrm{~ns}$ & $3.9 \mathrm{~ns}$ \\
\hline SxE Int. & 9 & $1174893 * * *$ & $45.004 \mathrm{~ns}$ & $0.0529 *$ & $32.9 *$ \\
\hline RxE Int. & 9 & $1518023 * * *$ & $32.345 \mathrm{~ns}$ & $0.0641 * *$ & $21.5 \mathrm{~ns}$ \\
\hline \multicolumn{6}{|l|}{ Model 2} \\
\hline Treatment & 15 & $2693846^{* * *}$ & $70.137 * *$ & $0.0455^{*}$ & $79.6^{* * *}$ \\
\hline $\mathrm{TxE}$ & 45 & $668996^{* *}$ & $43.246^{*}$ & $0.0530 * * *$ & $26.0 * *$ \\
\hline
\end{tabular}

Note. *** $(\mathrm{P}<0.001) ; * *(\mathrm{P}<0.01) ; *(\mathrm{P}<0.05) ;$ nsnon-significant; $\mathrm{SV}=$ Source of variation; $\mathrm{DF}=$ Degree of freedom MS = Mean Square; GY = Grain Yield; $\% \mathrm{~F}=$ Percent of filled grains; $\mathrm{W} 100 \mathrm{G}=100$ grains weight; $\mathrm{H}=$ Height; $\mathrm{S} \times \mathrm{R}$ Int. $=$ Spacing $\times$ rate interaction; $\mathrm{S} \times \mathrm{E}$ Int. $=$ spacing $\times$ environment interaction; $\mathrm{R} \times \mathrm{E}$ Int. $=$ rate $\times$ environment interaction; $\mathrm{T} \times \mathrm{E}=$ treatment $\times$ environment.

Tables 2 and 3 show the average of Scott-Knott test (1974) for traits that were significant in the analyzis of variance for plant spacing, $N$ rate and treatment. Grain yield was superior in small spacings $(20$ and $30 \mathrm{~cm})$ and in larger $\mathrm{N}$ rates $\left(120\right.$ and $\left.80 \mathrm{~kg} \mathrm{ha}^{-1}\right)$. When those two factors were analyzed together, it can be observed that treatment 4 obtained the best result for the grain yield trait (Table 3 ).

Table 2. Grain Yield $\left(\mathrm{kg} \mathrm{ha}^{-1}\right)$, percentage of filled grains and plant height $(\mathrm{cm})$ of BRSMG Caravera cultivar submitted to four $\mathrm{N}$ rates and four spacings

\begin{tabular}{lllllll}
\hline Spacing & GY & $\% \mathrm{~F}$ & $\mathrm{H}$ & N Rate & GY & $\mathrm{H}$ \\
\hline 20 & $3896.35 \mathrm{a}$ & $75.80 \mathrm{~b}$ & $83.45 \mathrm{a}$ & 120 & $3926.25 \mathrm{a}$ & $88.20 \mathrm{~d}$ \\
30 & $3778.93 \mathrm{a}$ & $77.66 \mathrm{a}$ & $85.20 \mathrm{~b}$ & 80 & $3690.52 \mathrm{a}$ & $85.81 \mathrm{c}$ \\
40 & $3442.10 \mathrm{~b}$ & $76.25 \mathrm{~b}$ & $87.08 \mathrm{c}$ & 40 & $3469.06 \mathrm{~b}$ & $84.22 \mathrm{~b}$ \\
50 & $3065.75 \mathrm{c}$ & $78.17 \mathrm{a}$ & $85.02 \mathrm{~b}$ & 0 & $3097.31 \mathrm{c}$ & $82.52 \mathrm{a}$ \\
\hline
\end{tabular}

Note. Means followed by the same letter do not differ at $5 \%$ probability by Scott-Knott test (1974); GY = Grain Yield; $\% \mathrm{~F}=$ percentage of filled grains; $\mathrm{H}=$ Height.

Table 3. Grain Yield $\left(\mathrm{kg} \mathrm{ha}^{-1}\right)$, percent of filled grains, 100 grains weight (grams) and plant height $(\mathrm{cm})$ BRSMG Caravera cultivar submitted to sixteen treatments $\left(\mathrm{N}\right.$ rate ${ }^{*}$ spacing combination)

\begin{tabular}{lllllll}
\hline Treatment & Spacing & N Rate & GY & $\% F$ & W100G & H \\
\hline 1 & 20 & 0 & $3312.00 \mathrm{c}$ & $74.71 \mathrm{~b}$ & $2.42 \mathrm{~b}$ & $80.50 \mathrm{a}$ \\
2 & 20 & 40 & $3873.25 \mathrm{~b}$ & $76.55 \mathrm{~b}$ & $2.37 \mathrm{~b}$ & $83.41 \mathrm{a}$ \\
3 & 20 & 80 & $3948.50 \mathrm{~b}$ & $76.70 \mathrm{~b}$ & $2.42 \mathrm{~b}$ & $83.91 \mathrm{a}$ \\
4 & 20 & 120 & $4451.66 \mathrm{a}$ & $75.21 \mathrm{~b}$ & $2.42 \mathrm{~b}$ & $86.00 \mathrm{~b}$ \\
5 & 30 & 0 & $3427.83 \mathrm{c}$ & $79.75 \mathrm{a}$ & $2.36 \mathrm{~b}$ & $83.00 \mathrm{a}$ \\
6 & 30 & 40 & $3857.83 \mathrm{~b}$ & $77.84 \mathrm{a}$ & $2.46 \mathrm{a}$ & $83.58 \mathrm{a}$ \\
7 & 30 & 80 & $3834.50 \mathrm{~b}$ & $76.99 \mathrm{~b}$ & $2.48 \mathrm{a}$ & $85.91 \mathrm{~b}$ \\
8 & 30 & 120 & $3995.58 \mathrm{~b}$ & $76.05 \mathrm{~b}$ & $2.39 \mathrm{~b}$ & $88.33 \mathrm{c}$ \\
9 & 40 & 0 & $3006.08 \mathrm{~d}$ & $74.62 \mathrm{~b}$ & $2.49 \mathrm{a}$ & $83.75 \mathrm{a}$ \\
10 & 40 & 40 & $3311.83 \mathrm{c}$ & $77.75 \mathrm{a}$ & $2.52 \mathrm{a}$ & $86.25 \mathrm{~b}$ \\
11 & 40 & 80 & $3738.08 \mathrm{~b}$ & $74.40 \mathrm{~b}$ & $2.40 \mathrm{~b}$ & $88.00 \mathrm{c}$ \\
12 & 40 & 120 & $3712.41 \mathrm{~b}$ & $78.25 \mathrm{a}$ & $2.42 \mathrm{~b}$ & $90.33 \mathrm{c}$ \\
13 & 50 & 0 & $2643.33 \mathrm{~d}$ & $80.20 \mathrm{a}$ & $2.38 \mathrm{~b}$ & $82.83 \mathrm{a}$ \\
14 & 50 & 40 & $2833.33 \mathrm{~d}$ & $81.53 \mathrm{a}$ & $2.59 \mathrm{a}$ & $83.66 \mathrm{a}$ \\
15 & 50 & 80 & $3241.00 \mathrm{c}$ & $78.63 \mathrm{a}$ & $2.47 \mathrm{a}$ & $85.41 \mathrm{~b}$ \\
16 & 50 & 120 & $3545.33 \mathrm{~b}$ & $72.32 \mathrm{~b}$ & $2.40 \mathrm{~b}$ & $88.16 \mathrm{c}$ \\
\hline
\end{tabular}

Note. Means followed by the same letter do not differ at $5 \%$ probability by Scott-Knott test (1974); GY = Grain Yield; $\% \mathrm{~F}=$ percentage of filled grains; $\mathrm{W} 100 \mathrm{G}=100$ grains weight; $\mathrm{H}=$ Height. 
Analyzing the breakdown of spacing $\times$ environment interaction, it was observed that there was a significant interaction of all spacings for grain yield and 100 grains weight (Table 4). For plant height, only the $20 \mathrm{~cm}$ spacing was not significant, or has not changed the cultivar performance in the environments. Regarding the traits that significantly changed depending of the $\mathrm{N}$ rate $\times$ environment interaction (DXE interaction), all $\mathrm{N}$ rates contributed to the interaction, or significantly altered the cultivar performance in different environments (Table 5).

Table 4. Summary of spacings per environment interaction for traits that showed significant interaction in the analysis of variance

\begin{tabular}{lllll}
\hline SV & DF & MS_GY & MS_W100G & MS_H \\
\hline Spacing & 3 & $6695074^{* * *}$ & $0.0313 \mathrm{~ns}$ & $105.8^{* *}$ \\
Env: Spa. & 12 & $7647431^{* * *}$ & $0.3187^{* * *}$ & $2481.8^{* * *}$ \\
$\quad$ Env: Spa.20 cm & 1 & $7332813^{* * *}$ & $0.3969^{* * *}$ & $34.0 \mathrm{~ns}$ \\
Env: Spa.30 cm & 1 & $3412333^{*}$ & $0.3782^{* *}$ & $230.0^{* *}$ \\
Env: Spa.40 cm & 1 & $17418798^{* * *}$ & $0.4624^{* * *}$ & $336.1^{* * *}$ \\
Env: Spa.50 cm & 1 & $21843160^{* * *}$ & $1.4121^{* * *}$ & $146.0^{*}$ \\
\hline
\end{tabular}

Note. *** $(\mathrm{P}<0.001)$; ** $(\mathrm{P}<0.01)$; $(\mathrm{P}<0.05)$; nsnon-significant; $\mathrm{SV}=$ Source of variation; $\mathrm{DF}=\mathrm{Degree}$ of freedom; MS = Mean Square; GY = Grain Yield; W100G = 100 grains weight; H = Height; Env: Spa = Environments within the spacing.

Table 5. Summary of $\mathrm{N}$ rates per environment interaction for traits that showed significant interaction in the analysis of variance

\begin{tabular}{llll}
\hline SV & DF & MS GY & MS W100G \\
\hline N rate & 3 & $5963456^{* * *}$ & $0.0641 \mathrm{~ns}$ \\
Env: Rate & 12 & $7904778^{* * *}$ & $0.3271^{* * *}$ \\
$\quad$ Env: Rate $20 \mathrm{~kg} \cdot \mathrm{ha}^{-1}$ & 1 & $8766041^{* * *}$ & $1.7867 * * *$ \\
$\quad$ Env: Rate $40 \mathrm{~kg} \cdot \mathrm{ha}^{-1}$ & 1 & $4945064 * *$ & $0.3403 * *$ \\
$\quad$ Env: Rate $80 \mathrm{~kg} \cdot \mathrm{ha}^{-1}$ & 1 & $16894144 * * *$ & $0.3403^{* *}$ \\
$\quad$ Env: Rate 120kg.ha & 1 & $16872925^{* * *}$ & $0.4613^{* * *}$
\end{tabular}

Note. $* * * \overline{(\mathrm{P}<0.001)}$;** $(\mathrm{P}<0.01) ; *(\mathrm{P}<0.05) ;$ nsnon-significant; $\mathrm{SV}=$ Source of variation; $\mathrm{DF}=\mathrm{Degree}$ of freedom MS = Mean Square; GY = Grain Yield; W100G = 100 grains weight; Env: Rate = Environment within the rate.

For grain yield, treatments 3, 5, 9, 10 and 11 contributed to interactions with the environment, i.e., cultivars subjected to these treatments had different performance in the environments (Table 6). For other traits, just a few treatments have contributed to the interaction. 
Table 6. Summary of treatments per environment interaction for traits that showed significant interaction in the analysis of variance

\begin{tabular}{|c|c|c|c|c|c|}
\hline SV & DF & MS GY & MS \%F & MS W100G & MS H \\
\hline Environment & 3 & $27065044 * * *$ & $286.81 * * *$ & $1.1159 * * *$ & $9829 * * *$ \\
\hline Env: Treat & 60 & $1175209 * * *$ & $49.97 *$ & $0.0512 * *$ & $39 * *$ \\
\hline Env: Treat 1 & 1 & $236531 \mathrm{~ns}$ & $37.81 \mathrm{~ns}$ & $0.0011 \mathrm{~ns}$ & $9 \mathrm{~ns}$ \\
\hline Env: Treat 2 & 1 & $404275 \mathrm{~ns}$ & $27.11 \mathrm{~ns}$ & $0.0004 \mathrm{~ns}$ & $6 \mathrm{~ns}$ \\
\hline Env: Treat 3 & 1 & $3098550 *$ & $2.57 \mathrm{~ns}$ & $0.0045 \mathrm{~ns}$ & $36 \mathrm{~ns}$ \\
\hline Env: Treat 4 & 1 & 536336ns & $30.42 \mathrm{~ns}$ & $0.1383^{*}$ & $2 \mathrm{~ns}$ \\
\hline Env: Treat 5 & 1 & $3235750 *$ & $12.86 \mathrm{~ns}$ & $0.0762 \mathrm{~ns}$ & $56 \mathrm{~ns}$ \\
\hline Env: Treat 6 & 1 & $702602 \mathrm{~ns}$ & $15.03 \mathrm{~ns}$ & $0.0230 \mathrm{~ns}$ & $3 \mathrm{~ns}$ \\
\hline Env: Treat 7 & 1 & $1940336 \mathrm{~ns}$ & $104.84 \mathrm{~ns}$ & $0.0630 \mathrm{~ns}$ & $183 * *$ \\
\hline Env: Treat 8 & 1 & $971065 \mathrm{~ns}$ & $0.46 \mathrm{~ns}$ & $0.0000 \mathrm{~ns}$ & $32 \mathrm{~ns}$ \\
\hline Env: Treat 9 & 1 & $8219156^{* * *}$ & $216.73 *$ & $0.0004 \mathrm{~ns}$ & $32 \mathrm{~ns}$ \\
\hline Env: Treat 10 & 1 & $3737693 * *$ & $0.00 \mathrm{~ns}$ & $0.1283^{*}$ & $9 \mathrm{~ns}$ \\
\hline Env: Treat 11 & 1 & $2375341 *$ & $19.43 \mathrm{~ns}$ & $0.0727 \mathrm{~ns}$ & Ons \\
\hline Env: Treat 12 & 1 & $298762 \mathrm{~ns}$ & $37.45 \mathrm{~ns}$ & $0.0589 \mathrm{~ns}$ & $18 \mathrm{~ns}$ \\
\hline Env: Treat 13 & 1 & $5280 \mathrm{~ns}$ & $124.10 \mathrm{~ns}$ & $0.0046 \mathrm{~ns}$ & $8 \mathrm{~ns}$ \\
\hline Env: Treat 14 & 1 & $1288560 \mathrm{~ns}$ & $20.06 \mathrm{~ns}$ & $0.0384 \mathrm{~ns}$ & $11 \mathrm{~ns}$ \\
\hline Env: Treat 15 & 1 & $193614 \mathrm{~ns}$ & $3.42 \mathrm{~ns}$ & $0.0123 \mathrm{~ns}$ & $74 \mathrm{~ns}$ \\
\hline Env: Treat 16 & 1 & $680207 \mathrm{~ns}$ & $1.44 \mathrm{~ns}$ & $0.0687 \mathrm{~ns}$ & $5 \mathrm{~ns}$ \\
\hline
\end{tabular}

Note. $* * *(\mathrm{P}<0.001) ; * *(\mathrm{P}<0.01) ; *(\mathrm{P}<0.05) ;$ nsnon-significant; $\mathrm{SV}=$ Source of variation; $\mathrm{DF}=$ Degree of freedom MS = Mean Square; $\mathrm{GY}=$ Grain Yield; $\% \mathrm{~F}=$ Percent of filled grains; $\mathrm{W} 100 \mathrm{G}=100$ grains weight; Env: Treat $=$ Environments within the treatments.

\section{Discussion}

According to Soares (2005), nitrogen is the nutrient that most contributes to grain yield increase in rice. During the vegetative phase, $\mathrm{N}$ is important to increase the number of tillers and panicles. $\mathrm{m}^{-2}$. In the reproductive phase, it increases the number of spikelets per panicle, and in the maturation phase, nitrogen is important to keep the green leaves for photosynthesis, increasing the percentage of filled grains.

In the present study, better results were obtained when a larger $\mathrm{N}$ rate was used, mainly the dose of $120 \mathrm{~kg} \mathrm{ha}^{-1}$. Lopes et al. (2013) found similar results evaluating the IAC-202 cultivar in two growing seasons. Using five $\mathrm{N}$ rates $\left(0,50,100,150\right.$ and $\left.200 \mathrm{~kg} \mathrm{ha}^{-1}\right)$ the authors observed that the highest productivity in the first year occurred with $\mathrm{N}$ rate of $150 \mathrm{~kg} \mathrm{ha}^{-1}$, and in the second year was with rate of $200 \mathrm{~kg} \mathrm{ha}^{-1}$.

Hernandez et al. (2010) observed that the highest yield was achieved with $122 \mathrm{~kg} \mathrm{ha}^{-1}$, regardless of the source of $\mathrm{N}$ used, which also supports the results obtained.

However, Fidelis et al. (2012) reported that of seven upland rice cultivars evaluated only one increased its grain yield with increasing $\mathrm{N}$ rate of $20 \mathrm{~kg} \mathrm{ha}^{-1}$ to $120 \mathrm{~kg} \mathrm{ha}^{-1}$. Mauad et al. (2003) found that high nitrogen levels reduced grain yield, once it induces tillering and formation of new leaves, favoring the onset of diseases, lodging and drop in productivity. Thus, there is not a general recommendation for nitrogen fertilizer in rice, as the response in grain yield varies significantly depending on the cultivar, environmental conditions, water management and soil properties.

Although plant spacing, $\mathrm{N}$ rate and $\mathrm{S} \times \mathrm{R}$ interaction were not significant in some cases, when those two factors were considered together (Treatment effect), there was significant differences for all traits, as well as interaction with the environment $(\mathrm{T} \times \mathrm{E}$ interaction) (Table1). This result indicates that these factors should be considered together, as there are combinations of $\mathrm{N}$ rates and spacings that were superior to all traits.

Several studies have shown that the reduction of row spacing when compared to the common spacing used in rainfed system $(50 \mathrm{~cm}$ ) increased grain yield (Araújo et al., 2014; Carvalho et al., 2008; Guimarães \& Pedra, 2003; Santos et al., 2002). Modern cultivars of upland rice have lower size and erect and short leaves, which allowed the consolidation of cultivation lines, increasing the number of plants per area and, consequently, the grain yield. 
According to Fornasieri Filho and Fornasieri (1993), rice grain yield is determined by number of panicles. $\mathrm{m}^{-2}$, number of spikelet. panicles ${ }^{-1}$, percentage of fertile spikelets and 100 grains weight. Although there was no significant effect of plant spacing and $\mathrm{N}$ rate for the 100 grains weight trait, it was observed treatments with best value for this trait, particularly involving larger spacings. Spacing of $20 \mathrm{~cm}$ resulted in low averages for the weight of 100 grain and percentage of full grain traits (Table 3). Plant spacing and density has a direct effect on these components, making it possible to choose the best combination of these factors thus obtaining high grain yield.

The effect of nitrogen in plant height is often reported in the literature for different upland rice cultivars used in this study and considering different $\mathrm{N}$ rates and sources (Fidelis et al., 2012; Araújo et al., 2014; Hernandes et al., 2010; Lopes et al., 2013). In all studies, increasing $\mathrm{N}$ rate led to an increase in plant height, and consequently the number of bedridden plants. This nutrient has a structural function and participates in metabolic processes influencing the expansion of leaf area and dry weight (Uhart \& Andrade, 1995). Thus, nitrogen stimulates plant growth, increases the number of stems and panicles per area (Farinelli et al., 2004).

However, as well as grain yield, the effect of fertilizer with nitrogen in plant height is variable, depending on factors such as light, temperature and humidity, becoming important to evaluate the effect of these factors on cultivars of interest in each environment.

Compared to grain yield, there was less variation for plant height both for increasing $\mathrm{N}$ rate as for different plant spacings in the four environments (Table 3). Analyzing both factors together, there was a subtle variation between treatments for Lavras 2012/2013 environment, but little variation for other environments. Thus, even if the height of plants has shown significant variation in environment averages, when analyzing the environments separately, it is noted little variation.

The small variation in averages for plant height in the environments indicates that the treatments did not significantly affect this trait in these locations. This is a very positive result because it allows the use of higher $\mathrm{N}$ rates and smaller spacings in order to increase grain yield without significantly interfering plant height, which could cause lodging and impair rice harvest.

According to Conab (2018), the average grain yield of upland rice in Brazil is $2400 \mathrm{~kg} /$ ha. Treatment 7, with the best result, presented value almost twice higher than the average. This demonstrates that the use of modern cultivars, the adequate spacing and $\mathrm{N}$ dose can significantly increase grain yield in upland rice cultivation.

\section{Conclusions}

BRSMG Caravera modern rice cultivar showed higher grain yield when using the highest $\mathrm{N}$ rate $\left(120 \mathrm{~kg} \mathrm{ha}^{-1}\right)$ and the smallest spacing between crop rows $(20 \mathrm{~cm})$, without compromising plant height.

It must be held together the analysis of factors once it allows combinations of $\mathrm{N}$ rates and higher spacings, as well as interaction with the environment.

Use of modern rice cultivars associated with technology and proper conduct can increase grain yield and competitiveness of upland rice cultivation, in the state of Minas Gerais, Brazil.

\section{Acknowledgments}

The authors thank the Fundação de Apoio a Pesquisa de Minas Gerais (FAPEMIG), the Coordenação de Aperfeiçoamento de Pessoal de Nível Superior (CAPES), and The Conselho Nacional de Desenvolvimento Científico e Tecnológico (CNPq), for financial support and scholarships.

\section{References}

Araújo, R., Jakelaitis, A., Oliveira, A. A., Pittelkow, F. K., Quaresma, J. P. S., \& Tavares, C. J. (2014). Cultivares, espaçamento entre linhas e parcelamento do nitrogênio em arroz de terras altas. Gl. Sci. Technol., 07(03), 26-35. https://doi.org/10.14688/1984-3801/gst.v7n3p26-35

Carvalho, J. A., Soares, A. A., \& Reis, M. S. (2008). Efeito de espaçamento e densidade de semeadura sobre a produtividade e os componentes de produção da cultivarde arroz BRSMG Conai. Ciência e Agrotecnologia, 32(3), 785-791. https://doi.org/10.1590/S1413-70542008000300012

CONAB. (2017). Acompanhamento da Safra Brasileira de Grãos 2016/17-Quarto Levantamento, Janeiro. Retrieved from http://www.conab.gov.br/OlalaCMS/uploads/arquivos/16_01_12_09_00_46_boletim_graos janeiro_2017.pdf 
Farinelli, R. (2004). Características agronômicas de arroz de terras altas sob plantio direto e adubação nitrogenada e potássica. Revista Brasileira de Ciência do Solo, 28(3), 447-454. https://doi.org/10.1590/ S0100-06832004000300006

Fidelis, R. R., Rodrigues, A. M., Silva, G. F., Barros, H. B., Pinto, L. C., \& Aguiar, R. W. S. (2012). Eficiência do uso do nitrogennio em arroz de terras altas. Pesquisa Agropecuária Tropical, 42(1), 124-128. https://doi.org/10.1590/S1983-40632012000100018

Fornasieri Filho, D., \& Fornasieri, J. L. (1993). Manual da cultura do arroz (p. 221). Jaboticabal: FUNEP.

Guimarães, C. M., Stone, L. F., \& Silva, F. X. (2003). Espaçamento entre linhas para o arroz de terras altascom arquitetura de planta moderna. Santo Antônio de Goiás: Embrapa Arroz e Feijão.

Hernandes, A. (2010). Doses, fontes e épocas de aplicação de nitrogênio em cultivares de arroz. Ciência e Agrotecnologia, 34(2), 307-312. https://doi.org/10.1590/S1413-70542010000200006

Lopes, R. A., Buzetti, S., Teixeira Filho, M. C. M., Benett, C. G. S., \& Arf, M. V. (2013). Doses, fontes e épocas de aplicação de nitrogênio em arroz de terras altas cultivado em sistema de semeadura direta. Revista Caatinga, 26(4), 79-87.

Mauad, M. (2003). Nitrogen and silicon fertilization of upland rice. Scientia Agricola, 60(4), 761-765. https://doi.org/10.1590/S0103-90162003000400023

Minas, G. (1995). Secretaria de Estado da Agricultura, Pecuária e Abastecimento. Cenário futuro do negócio agrícola de Minas Gerais. Belo Horizonte, 3, 57.

R Development Core Team. (2012). R: A language and environment for statistical computing. R Foundation for StatisticalComputing, Vienna.

Sant'ana, E. P. (1989). Cultivo do arroz irrigado por aspersão. Informe Agropecuário. Arroz de sequeiro: novas perspectivas para o produto. Belo Horizonte: EPAMIG, 14(161), 61-69.

Santos, P. G., Soares, A. A., \& Reis, M. S. (2002). Efeito do espaçamento e densidade de semeadura sobre a produção de arroz de terras altas irrigado por aspersão. Ciência e Agrotecnologia, 26(3), 480-487.

Scott, A., \& Knott, M. (1974). Cluster-analysis method for grouping means in analysis of variance. Biometrics, 30(3), 507-512. https://doi.org/10.2307/2529204

Soares, A. A. (2005). Cultura do arroz (2nd ed., p. 130). Lavras: UFLA/FAEPE.

Uhart, A. S., \& Andrade, F. H. (1995). Nitrogen deficiency in maize: I-Effects on crop, growth, development, dry matter partitioning and kernel sets. Crop Science, 35(5), 1376-1383. https://doi.org/10.2135/ cropsci1995.0011183X003500050020x

\section{Copyrights}

Copyright for this article is retained by the author(s), with first publication rights granted to the journal.

This is an open-access article distributed under the terms and conditions of the Creative Commons Attribution license (http://creativecommons.org/licenses/by/4.0/). 